\title{
Propsilocerus seezanus sp.n. a new alpine element occurring in the oligotrophic high mountain Lake Seez, South Eastern France (Diptera, Chironomidae, Orthocladiinae)
}

\section{Propsilocerus seezanus sp.n. - новая альпийская хирономида, обитающая в олиготрофном высокогорном озере Сеез, Юго- Восточная Франщия (Diptera, Chironomidae, Orthocladiinae)}

\author{
J. Moubayed-Breil \\ Аж. МобайеА-Брейл
}

Consultant in Freshwater \& Marine biology, 10 rue des Fenouils, Montpellier F-34070 France. E-mail: mvp5133@gmail.com. Консультант по пресноводной и морской биологии, 10 Рю де Фенуй, Монтпелье F-34070 Франция.

Key words: Chironomidae, Propsilocerus, new species, Lake Seez, French Alps.

Ключевые слова: Chironomidae, Propsilocerus, новый вид, озеро Сеез, Французские Альпы.

\begin{abstract}
Propsilocerus seezanus sp.n. is described and diagnosed based on material composed of male adults collected in the oligotrophic high mountain Lake Seez located in the French Alps (E-France). In this paper the diagnosis of the genus Propsilocerus Kieffer (1923) is supplemented with some additional relevant characters found in the male adult. The new species is keyed near P. jacuticus (Zvereva, 1950), $P$. paradoxus (Lundstrom, 1915) and $P$. sinicus Sæther et Wang, 1996, from which it can be separated by the following characters: only outer verticals present; squama of wing bare; tibial pseudospurs present on $\mathrm{P}_{\mathrm{I}}-\mathrm{P}_{\mathrm{III}}$, hind tibial comb present, sensilla chaetica present on tibia and tarsomeres; tergite IX sub-rectangular and markedly projecting posteriorolaterally; superior and median volsella consist of 1 small lobe bearing each 1 single apical stout seta. Geographical distribution of $P$. seezanus sp.n. is currently restricted to the French Alps. It belongs to the community of glacial relic elements, which are considered as biogeographic indicators of global warming and climate change. Remarks, taxonomic position, and ecology of the new described species are given.
\end{abstract}

Резюме. Приведено описание нового вида ортокладиин Propsilocerus seezanus sp.n. по материалу из высокогорного олиготрофного озера Сеез во Французских Альпах (Юго-Восточная Франция). Диагноз рода Propsilocerus Kieffer, 1923 дополнен новыми признаками, обнаруженными у самца нового вида. По имаго самцу $P$. seezanus sp.n. близок P. jacuticus (Zvereva, 1950), P. paradoxus (Lundstrom, 1915) и $P$. sinicus Sæther et Wang, 1996, от которых отличается следующими признаками: на голове присутствуют только наружные вертикальные щетинки; чешуйка крыла голая; на голени $\mathrm{P}_{\mathrm{I}}-\mathrm{P}_{\text {III }}$ имеются ложные шпоры, голень задней ноги с гребнем, на голени и члениках лапки имеется сенсилла хетика; тергит IX почти прямоугольный, с выступающими частями постериолатерально; верхние и средние придатки гонококсита в виде маленьких выпячиваний, на каждом из которых по одной апикальной сильной щетинке. Распространение $P$. seezanus sp.n. ограничено Французскими Альпами. Этот вид относится к сообществу ледниковых реликтовых элементов. Также рассмотрено таксономическое положение нового вида и приведены данные по его экологии.

\section{Introduction}

Knowledge and database provided on the taxonomy, geographical distribution and ecology of the genus Propsilocerus Kieffer, 1923 [Kieffer, 1923; Sasa, 1978; Sæther, Wang, 1996; Sæther, 1997; Zelentzov, 2000; Wang, Sæther, 2001; Wang et al., 2007; Makarchenko, Makarchenko, 2008; Cranston et al., 1989; Ashe, O’Connor, 2012; Sæther, Spies, 2013; Moubayed-Breil, Ashe, 2016] shows that worldwide there are nine valid species currently known from Europe and the Palaearctic Region. In this paper a tenth additional new species P. seezanus sp.n. is described based on material collected in the glacial Lake Seez located in the French Alps (E-France, altitude $2457 \mathrm{~m}$ ).

$P$. seezanus sp.n. apparently belongs to a separate group, which probably includes the three following related species: P. jacuticus (Zvereva, 1950), P. paradoxus (Lundstrom, 1915), P. sinicus Sæther et Wang, 1996. The new described species is only known from the high mountain oligotrophic Lake Seez. The recent updated list of 766 species previously provided in Moubayed-Breil and Ashe [2016], Moubayed-Breil [2017] and Moubayed-Breil and Dia [2017] is currently upgraded to 767 known Chironomid species from continental France. Remarks and discussion on some related Propsilocerus species and comments on the ecology and geographical distribution of the new species are given.

\section{Material and methods}

Material of male adults were collected using a sweep entomological net around the Lake Seez including shelters and small shaded habitats between rocks. All samples were preserved in $90 \%$ Ethanol. Male adults were cleared of musculature in $90 \%$ lactic acid (head, thorax, abdomen and anal segment) for about 60 to 80 minutes, 
which can be left overnight at room temperature without any detrimental effect or damage. The specimens were checked under a binocular microscope after 20 minutes in lactic acid to determine how the clearing was progressing. When clearing was complete the specimens were washed in two changes of 50-60\% Ethanol to ensure that all traces of lactic acid were removed. Compared to clearing with potassium hydroxide, or other clearing solutions, no deterioration of the typical "original" structure is reported by using lactic acid. All examined material was mounted in polyvinyl lactophenol, remaining paratypes were preserved in $90 \%$ Ethanol. The eye on one side was dissected from the head, which ensures that the hairs on the inner margin of the eye are more clearly visible. Before the final slide mountings (dorsally) of the type and paratype material, the hypopygium including the tergum IX, the anal point, the gonocoxite and the gonostylus, were viewed ventrally and laterally to examine and draw from both sides all the necessary details of the species. In particular, the ventral view of hypopygium was illustrated when anal point and tergite IX were removed.

Morphological terminology and measurements largely follow that of Sæther [1980] and Cranston et al. [1989] for the imagines. For a better examination of the specific features and for a more accurate description of the various taxonomic details of the pupae, the pupal abdomen were mounted not only in dorsal and ventral view but separately in lateral view, which seems to illustrate all the necessary relevant taxonomic characters.

\section{Description}

\section{Propsilocerus seezanus Moubayed-Breil, sp.n. Figs. 1-14.}

Type material. Holotype: male adult, France, Alps, high mountain oligotrophic Lake Seez, altitude $2457 \mathrm{~m}$; leg. Gennaro Coppa, 16.VII.2017. Paratypes: 2 male adults, the same data as holotype. Holotype (on 1 slide) is deposited in the collections of the Zoologische Staatssammlung (ZSM), Munich, Germany. Paratypes: 1 male adult deposited in the collection of E. Makarchenko; 1 male adult housed in the author's collection.

Etymology. The species name «seezanus» belongs to the known Alpine glacial Lake Seez, which is situated in South Eastern area of the French Alps (altitude $2457 \mathrm{~m}$ ), where the type material is collected.

Diagnostic characters. The nearest Propsilocerus related species to $P$. seezanus sp.n. are $P$. jacuticus, $P$. paradoxus and $P$. sinicus from which the new described species can be separated by the following distinguishing characters: eyes with dense pubescence; only outer verticals present; sensilla coeloconica present on palpomeres 3 and 4; squama of wing bare; tibial pseudospurs present on $\mathrm{P}_{\mathrm{I}}-\mathrm{P}_{\mathrm{III}}$, hind tibial comb present, sensilla chaetica present on tibia and tarsomeres ( $\mathrm{ti}+$ $\mathrm{ta}_{1}-\mathrm{ta}_{5}$ of PI; $\mathrm{ti}+\mathrm{ta}_{1}-\mathrm{ta}_{4}$ of PIII); tergite IX sub-rectangular, posterior margin converging medially towards base of anal point, posterolateral corners markedly projecting outwards, about 50-60 setae present close to the posterior margin; base of anal point with about 15-16 setae; superior and median volsella consist of 1 small and large lobe bearing each 1 single apical stout seta. However, P. seezanus sp.n. apparently belongs to a separate group, which probably includes the two previously cited species.

Male imago $(\mathrm{n}=2$; Figs $1-14)$. Total length 3.30-3.40 $\mathrm{mm}$. Wing length $2.10-2.20 \mathrm{~mm}$; $\mathrm{TL} / \mathrm{WL}=1.55-1.57$. General colouration brown to dark brown with contrasting dark brown to blackish thorax, abdominal segments and anal segment. Thorax blackish with a contrasting humeral pit; legs dark brown to blackish; base of wing contrasting brownish to blackish.

Head. Eyes with dense pubescence, inner eye margin bare. Temporals consist of $2-3$ outer verticals, inner verticals absent. Palp 5-segmented; first and second palpomeres fused; length $(\mu \mathrm{m})$ of segments $15,55,105,110,175$; sensilla coeloconica present distally on palpomeres 3 and 4 (Figs 13 ), sensilla clavata only present on palpomere 4 (Fig. 1). Clypeus (Fig. 4) cup-like shaped with 8 setae placed in 3 rows. Antenna 1180-1210 $\mu \mathrm{m}$ long, 13-segmented; length (in $\mu \mathrm{m}$ ) of segments: $1,70 \mu \mathrm{m}$ long, $2-12$, sub-equal, about 25 $\mu \mathrm{m}$ long, ultimate flagellomere $830-860 \mu \mathrm{m}$ long, slightly clubbed and bearing a brush of curved sensilla chaetica apically; antennal groove beginning on segment 5 and reaching ultimate flagellomere. AR 2.38-2.46. Thorax. Lobes of antepronotum widely gaping, with 3 antepronotals; acrostichals absent; dorsocentrals, 8-9 in 1 row; humeral pit consists of a large discontinuous oval and contrasting rim; prealars 2-3; preepisternum bare. Scutellum with 8 setae in 1 row.

Wing. Brachiolum with 1 seta. Number of setae on veins: $\mathrm{R}, 12-13 ; \mathrm{R}_{2+3}, 4-5$ placed distally; remaining veins bare. Squama bare.

Legs. Length $(\mu \mathrm{m})$ and proportions of legs as in Table 1. Femur and tibia of PI and PII nearly sub-equal; presence of long setae (140-150 $\mu \mathrm{m}$ long) on tarsomere ta of PII and PIII, maximum value of BR (4.70) is recorded on PIII; pseudospurs present on tibia of $\mathrm{P}_{\mathrm{I}}-\mathrm{P}_{\mathrm{III}}$; sensilla chaetica present on tibia and tarsomeres: ta $\mathrm{ta} \mathrm{ta}_{5}$ of PI; $\mathrm{ta}_{1}$ to $\mathrm{ta}_{4}$ of $\mathrm{P}_{\text {III }}$

Abdomen. Hypopygium in dorsal ventral and lateral view as in Figs 9-14, ventral view (Fig. 10) with tergite IX and anal point removed. Tergite IX 185-190 $\mu \mathrm{m}$ long, 180-185 maximum width at base; sub-rectangular to nearly scare; posterior margin markedly converging towards base of anal point, posterolateral corners markedly projecting outwards; about $50-60$ setae are placed distally close to the posterior margin (25-30 on each side of anal point). Anal point $80-85 \mu \mathrm{m}$

Figs 1-14. Male imago of Propsilocerus seezanus sp.n. 1 - palpomeres $1-3 ; 2-$ details of sensilla coeloconica on palpomere 2; 3 - the same on palpomere 3; 4 - clypeus; 5 - antepronotum; 6 - squama of wing; 7 - tergite IX and anal point, in lateral view; 8 - the same, in dorsal view; 9 - hypopygium, in dorsal view (gonostylus removed); 10 - the same, in ventral view (tergite IX and gonostylus removed); 11 - base of gonocoxite with superior and median volsellae, in ventral view; 12 - superior and inferior volsellae, in lateral view; 13 - right gonostylus, in dorsal view; 14 - the same, in lateral view.

Рис. 1-14. Имаго самец of Propsilocerus seezanus sp.n. $1-1-3$ чменики максимлярного щупика; 2 - детали строения колоколовидного органа на 2-м чменике максимлярного щупика; 3 - то же на 3-м членике; 4 - клипеус; 5 - переднеспинка; 6 - чешуйка крыма; 7 - тергит IX и анальный отросток, виА сбоку; 8 - то же, виА сверху; 9 - гипопигий, виА сверху (гоностиль удалён); 10 - то же, виА снизу (тергит IX и гоностиль удалены); 11 - основание гонококсита с верхним и средним придатками, виА снизу; 12 - верхний и нижний придатки гонококсита, виА сбоку; 13 - правый гоностиль, виА сверху; $14-$ то же, виА сбоку. 


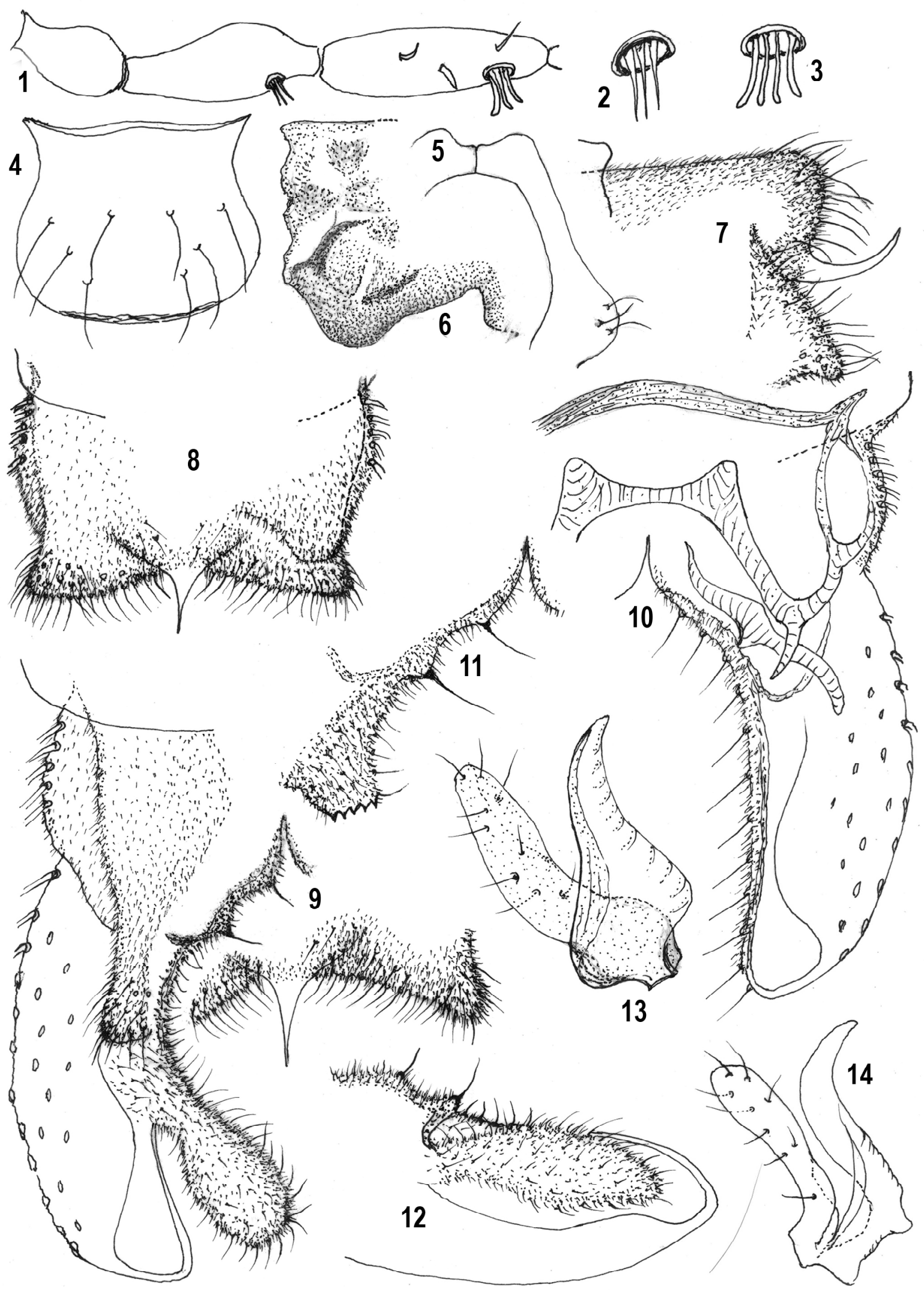


long, about $90 \mu \mathrm{m}$ wide at base; basal part semi-circular, strongly narrowing distally, with $15-16$ setae (7-8 setae on each side); distal part $30 \mu \mathrm{m}$ long, bare and sharply pointed apically. Laterosternite IX with 10 setae (5 on each side), extended vertically and ending with 2 lateral lobe-like expansions. Sternapodeme and phallapodeme as in Fig. 10, transverse sternapodeme $105 \mu \mathrm{m}$ long as long as the lateral expansion, orally produced to an arc-like with 2 lateral projecting tubercles; phallapodeme about $120 \mu \mathrm{m}$ long, linearly elongated, median margin with a small inner triangular tubercle. Gonocoxite (Figs 9-10, 12) about 250-260 $\mu \mathrm{m}$ long and 45 $\mu \mathrm{m}$ maximum wide; apex truncate; inner margin with 10-11 stout setae. Superior and median volsella (Figs 9, 11-12) consist of 2 sub-equal week lobes bearing each 1 stout seta apically. Inferior volsella about $150 \mu \mathrm{m}$ long and $45 \mu \mathrm{m}$ maximum wide; long tongue-like shaped and extended downwards; numerous cuved stout setae are present on inner and posterior margins. Gonostylus (Figs 13-14) composed of 2 hyaline parts, which are lacking megaseta: basal part 100 $105 \mu \mathrm{m}$ long, large at base and narrowing distally to a pointed apex; apical part 95-100 $\mu \mathrm{m}$ long, linearly and uniformly extended, with 9-10 short setae.

Pupa and larva unknown.

KEY DIFFERING NEW SPECIES FROM ALL KNOWN MALE ADULTS From Europe and the Oriental Region

1. Squama bare (Fig. 6); eyes with dense pubescence; only outer temporal verticals present, inner verticals absent; sensilla coeloconicum present on palpomeres 3 and 4 (Figs 1-3); pseudospurs present on tibia of $\mathrm{P}_{\mathrm{I}}-\mathrm{P}_{\text {III }}$; tergite IX (Figs 7-9) sub-rectangular, posterior margin converging medially towards base of anal point, posterolateral corners markedly projecting outwards; anal point semi-circular at base and sharply pointed apically, strongly curved upwards in lateral view (Fig. 7); superior and median volsella (Figs $9,11-12)$ consists of 2 week lobes, each bearing only 1 single apical seta; basal and apical parts of gonostylus (Figs 13-14) sub-equal, basal part bare...

Propsilocerus seezanus sp.n.

- Squama with more than 25 setae; eyes bare; inner verticals and pseudospurs absent or present; sensilla coeloconicum present only on palpomere 3 ; tergite IX and anal point not shaped as mentioned above; superior and median volsella consist of 1 single projecting lobe, with or without stout setae; basal and apical parts of gonostylus not as above . all other Propsilocerus species

Ecology and geographical distribution. Material of Propsilocerus seezanus sp.n. was collected in the basin of the high mountain Alpine lakes Seez, which is well known as glacial and oligotrophic lake. Emergence of adults is observed in July but is apparently extended to late summer and probably to the early autumn. Geographical distribution is actually restricted to Alpine lakes located in Eastern areas of continental France. P. seezanus sp. n. apparently belongs to a relict glacial element and is likely believed to characterize the Alpine glacial lakes where are reported other glacial relic species documented by Moubayed-Breil and Ashe [2016], MoubayedBreil and Dia [2017] and Moubayed-Breil and Lods-Crozet [2018]. This highlights the importance of some high glacial mountain range in the Alpine Region where constructive plans for conservation and preservation of autochthonous glacial relic species must be implanted. Such relic species are considered as biogeographic representative and biological indicators of global warming and climate change.

Associated species encountered around the basin of the Lake Seez include: Diamesa aberrata Lundbeck, 1898; D. bohemani, Goetghebuer, 1932; D. cinerella (Meigen, 1835); D. hyperborea Holmgren, 1869; D. latitarsis (Goetghebuer, 1921); D. modesta Serra-Tosio, 1967; D. thomasi SerraTosio, 1970; D. zernyi Edwards, 1933; Pseudodiamesa branickii (Nowicki, 1873); P. nivosa (Goetghebuer, 1928); Pseudokiefferiella parva (Edwards, 1932); Syndiamesa edwardsi (Pagast, 1947); S. hygropetrica (Kieffer, 1909).

\section{Acknowledgments}

I express my gratitude to my colleague Gennaro Coppa for collecting in the Lake Seez the type material of the new described species.

\section{References}

Ashe P., O'Connor J. 2012. A World Catalogue of Chironomidae (Diptera). Part 2. Orthocladiinae. Irish Biogeographical Society \& National Museum of Ireland, Dublin. P.1-968.

Cranston P.S., Oliver D.R., Sæther O.A. 1989. The adult males of Orthocladiinae (Diptera: Chironomidae) of the Holarctic Region - Keys and diagnoses. In: Wiederholm, T. (ed.): Chironomidae of the Holarctic region. Keys and diagnoses. Part 3 - Adult males // Entomologica scandinavica. Suppl.34. P.164-352.

Moubayed-Breil J. 2017. On the genus Chaetocladius (laminatusgroup). I. Taxonomic notes with description of $C$. guisseti sp. n. from glacial springs and streams located in Eastern Pyrenees (Diptera: Chironomidae, Orthocladiinae) // Evraziatskii Entomologicheskii Zhurnal (Euroasian Entomological Journal). Vol.16. No.5. P.487-500.

Moubayed-Breil J., Ashe P. 2016. New records and additions to the database on the geographical distribution of some threatened chironomid species from continental France (Diptera, Chironomidae) // Ephemera. Vol.16. No.2. P.121136.

Moubayed J., Dia A. 2017. Chaetocladius coppai sp.n. and C. diai sp.n., two mountain relic species inhabiting glacial springs and cold streams (Diptera: Chironomidae, Orthocladiinae) // Zoosystematica Rossica. Vol.26. No.2. P.369-380.

Moubayed-Breil J., Baranov V. 2018. Taxonomic notes on the genus Hydrobaenus Fries, 1830 with description of Hydrobaenus simferopolus sp.n. from the Crimean Peninsula, Ukraine (Diptera, Chironomlidae) // Acta Entomologica Musei Nationalis Pragae. In print.

Moubayed J., Lods-Crozet B. 2018. On the genus Chaetocladius s. str. Kieffer, 1911 from Switzerland with descriptions of five new relic species occurring in glacial alpine rheocrenes and streams (Diptera, Chironomidae) // Alpine Entomology. Vol.2. P.15-34

Sæther O.A. 1980. Glossary of chironomid morphology terminology (Diptera, Chironomidae) // Entomologica scandinavica. Suppl.14. P.1-51.

Sæther O.A. 1997. First description of the imagines and pupa of Propsilocerus jacuticus (Zvereva) (Diptera: Chironomidae) // Acta Zoologica. Academiae Scientiarium Hungaricae. Vol.43. No.3. P.241-249.

Sæther O.A., M. Spies. 2013. Fauna Europaea: Chironomidae // P. Beuk, T. Pape (Eds): Fauna Europaea: Diptera Nematocera. Fauna Europaea version 2.6. Internet data base at http:// www.faunaeur.org [accessed February 2015]. 